УДК 82I.I33.I

ББК $83.3(4 Ф$ ра $) 4$
АЛЛЕГОРИЯ, ПОЭТРИЯ, РИТОРИКА:

К ПОНЯТИЮ ПОЭТИЧЕСКОГО ВЫМЫСЛА ВО ФРАНЦИИ КОНЦА XV В.

\author{
(C) 2017 г. И.К. Стаф \\ Институт мировой литературы \\ им. А.М. Горького Российской академии наук, \\ Москва, Россия \\ Дата поступления статьи: 03 сентября 2017 г. \\ Дата публикации: 25 декабря 2017 г. \\ DOI: IO.22455/2500-4247-20I7-2-4-IO-29
}

Аннотация: Аллегорическое измерение текста в культуре раннего французского Возрождения стало (под влиянием «Генеалогии богов» Боккаччо) главным аргументом в защиту поэтического вымысла (fabula). Однако перенос идей Боккаччо на французскую почву сопровождался существенным переосмыслением основополагающих принципов его труда. Если в «Генеалогии...» истина, скрытая под покровом «басен», есть множество возможных толкований мифологического материала, складывающихся в единый макрокосм, то заальпийские последователи итальянского гуманиста - от августинца Жака Леграна, автора трактата «Красноречивейшая София Мудрость» (ок. I400) до анонимного автора «Олимпа историй поэтических» (I539), - следуя традиции как средневековой мифографии, так и средневековых переложений «Метаморфоз» Овидия, создают пространные перечни античных богов и персонажей, трактуя их как иносказательное поучение, наставление в истинной вере. Интерпретация оказывается первичной по отношению к мифологическому вымыслу, перемещая его в сферу «моральной философии» и превращая в exemplum, поучительный пример. Подобная экзегеза функционально приравнивает поэтические «басни» древних к библейским сюжетам: из тех и других «моральный философ» или проповедник может почерпнуть необходимый ему материал. Именно так понимает сущность и задачи науки о вымысле (poetrie) Жак Легран. Тем самым «поэтрия», каталог морализованных, разъятых на отдельные loci communes и классифицированных по категориям моральной философии вымыслов, становится частью риторики, проникая в некоторые трактаты по «второй риторике», т. е. стихотворству на народном языке. К началу XVI в. учение о fabula оказалось целиком подчинено принципу «украшенной речи», пополнив собой набор риторических фигур, необходимых оратору, а поэтический вымысел приобрел новый статус: сохраняя свою аллегорико-морализаторскую природу, он перестал нуждаться в эксплицитном толковании: образованный читатель получил право интерпретировать его без посредничества наставника-комментатора.

Ключевые слова: аллегория, вымысел, «Генеалогия языческих богов», «поэтрия», моральная философия, «Морализованный Овидий».

Информация об авторе: Ирина Карловна Стаф - кандидат филологических наук, старший научный сотрудник, Институт мировой литературы им. А.М. Горького Российской академии наук, ул. Поварская, д. 25 а, І21069 г. Москва, Россия.

E-mail: irina.staf@gmail.com 


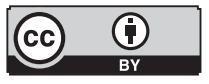

This is an open access article distributed under the Creative Commons Attribution 4.0 International (CC BY 4.0)

\section{ALLEGORY, POETRIE, RHETORIC: ON THE NOTION OF POETIC FICTION IN FRANCE AT THE END OF THE $15^{\text {TH }}$ CENTURY}

\author{
(C) 20I7. I.K. Staf \\ A.M. Gorky Institute of World Literature \\ of the Russian Academy of Sciences, Moscow, Russia \\ Received: September 03, 2017 \\ Date of publication: December 25, 2017
}

\begin{abstract}
The allegorical dimension of the text in the early French Renaissance culture became, under the influence of Boccaccio's Genealogy of the Pagan Gods, the main argument in the defense of poetic fiction (fabula). However, the transfer of Boccaccio's ideas to France was followed by significant reconsideration of his work's fundamental principles. Whereas in Genealogy, the truth (hidden under the veil of the "fables") is a series of virtual mythological interpretations that represent a solid macrocosm, French followers of the Italian humanist, from the Augustinian Jacques Legrand, author of the treatise Eloquent Sofia-Wisdom (ca. I400) to the anonymous author of The Poetic Stories of Olympus (I539), develop a different understanding. Bearing on the tradition of both medieval mythography and the medieval versions of Ovid's Metamorphosis, they form extensive lists of ancient Gods and characters, interpreting the ancient myth as figurative instruction in the true faith. Interpretation becomes primary to the myth thus moving the myth into the realm of "moral philosophy" and turning it into an exemplum, an instructive example. Such exegesis functionally equates poetic "fables" of the Ancient Greeks and Romans with Biblical plots: from both, a "moral philosopher" or preacher can draw the material he needs. This is how Jacques Legrand understands the essence and the tasks of the science of fiction (poetrie). "Poetrie," a catalogue of moralized fictional images and plots, separated into loci communes and classified according to the categories of moral philosophy, becomes part of the rhetoric as it penetrates into some treatises on the "second rhetoric," related to the verse in the national language. By the beginning of the $16^{\text {th }}$ century, the doctrine of the fabula became wholly subordinated by the principle of "decorated speech" and added to a set of rhetorical figures for the usage of the speaker. Poetic fiction acquired a new status: retaining its allegorical-moralizing nature, it ceased to require explicit interpretation. Educated reader became entitled to interpret it without mediation of the mentor or commentator.
\end{abstract}

Keywords: allegory, fiction, Genealogy of the Pagan Gods, poetrie, moral philosophy, "Moralized Ovid".

Information about the author: Irina K. Staf, PhD in Philology, A.M. Gorky Institute of World Literature of Russian Academy of Sciences, Povarskaya 25 a, I2I069 Moscow, Russia.

E-mail: irina.staf@gmail.com 
Понятие аллегории приобрело в культуре раннего французского Возрождения особую значимость в рамках одной из ключевых концепций литературной и философской мысли эпохи - концепции poeta teologo, проникшей во Францию под сильным влиянием «Генеалогии языческих богов» Боккаччо: аллегорическое измерение текста служило главным аргументом для оправдания поэзии, т. е. поэтического вымысла (fabula). Между тем трактовка этого понятия в гуманистической традиции была предельно широкой. Поскольку этимологически $\dot{\alpha} \lambda \lambda \eta \gamma о \rho i \alpha$ означает любое иносказание (или «инопрочтение»), она покрывает собой и метафору, и метонимию, и загадку, и эмблему, и комментарий, и чрезвычайно важное для раннеренессансной культуры понятие translatio («перенос, переложение») [5, p. 76-78]. Более того, «аллегория» означает одновременно и поэтический материал, подлежащий истолкованию, и способ его интерпретации, призванной выявить и эксплицировать «скрытый смысл» текста. Однако, как справедливо отмечает Э. Кампань, «отсутствие формальных и точных объяснений аллегории-глоссы, в противоположность множеству определений, которые дают учебники риторики, заставляет полагать, что вопрос о двойственности аллегории для теоретиков того времени фактически не стоял» [5, p. 49].

Можно предположить, что такое «недифференцированное» понимание аллегории связано не с отсутствием рефлексии и разработанного категориального аппарата, но с представлением о сущности и функциях поэзии в предренессансный период. Мы попытаемся показать на примере нескольких французских теоретических трактатов XV - начала XVI вв., какое место занимали fabulae в новой концепции поэзии, которая складывалась 
после «Искусства сочинять» (Art de Dictier, г393) Эсташа Дешана и в рамках которой национальные поэтические и риторические традиции приходили во взаимодействие с новыми гуманистическими идеями.

В «Генеалогии богов» поэзия именуется «неким пылом изящного изобретения, ... <ккоторый> внушает душе стремление говорить, изобретать чудные и неслыханные вещи, с глубоким смыслом сочетать их в стройном порядке, украшать сочиняемое непривычными сплетениями слов и суждений и скрывать истину под мифическим и благолепным покровом» [I, c. 25-26]. Боккаччо различает четыре вида поэтических «басен» (fabulae), исходя из соотношения в них истины и вымысла (и, соответственно, возможных способов их интерпретации). К первой категории относятся чисто аллегорические тексты, лишенные «всякого правдоподобия», т. е. собственно эзоповы басни; ко второй - те, где вымысел соседствует с правдой, а аллегория - с подражанием природе, как в «Метаморфозах» Овидия; третий вид, «больше подобный истории, чем басне», включает в себя эпос, основанный на подражании природе и на аллегории, и моральные сочинения комических поэтов, подобных Плавту и Теренцию, т. е. чистое imitatio; и наконец, «четвертый вид басен совсем не содержит никакой ни внешней, ни прикровенной правды, это просто выдумки полоумных старух» [I, с. 31 $]^{\mathrm{T}}$. В любом, даже самом ничтожном вымысле присутствует гносеологическое измерение, а следовательно, понятие поэзии включает в себя любое повествование, в котором присутствует вымысел: именно его наличие отличает поэзию и науку о ней от риторики ${ }^{2}$. «Вымысел есть главная, определяющая черта поэзии в силу того факта, что он - всегда покров (“velamen”) некоей общей истины, применительно к которой аллегория как инвенция выступает своего рода мимесисом наоборот» [20, р. 59].

Трактат получил во Франции меньшую известность, нежели другие произведения Боккаччо, однако знакомство с ним первых французских гуманистов из окружения Карла VI (Гонтье Коля, Жана де Монтрёйя, Лорана де Премьефе) не подлежит сомнению. При этом две его последние, XIV и

I Право последней категории принадлежать к поэзии обосновывается в конце го главы: «Нет настолько спятившей старухи из тех, что у домашнего очага придумывают или рассказывают зимними вечерами басни о мертвецах, феях, привидениях и подобных вещах, часто и для поэзии служащих материей, которая бы за этими рассказами по силам малого своего ума не подразумевала какого-нибудь смысла, иногда далеко не смехотворного...» [1, с. 34].

2 «Только ведь в риторике ничто не выступает в оболочке вымысла...» [I, c. 27]. 
$\mathrm{XV}$ книги, содержащие похвальное слово поэзии как «новому богословию», довольно быстро обрели автономное существованиез, сделавшись образцом и одним из главных источников идей для новой науки о поэзии - поэтрии (poetrie). По-видимому, первым опытом их теоретической рецепции стал обнаруженный в самом начале г970-х гг. трактат «Доказательство искусства поэтики» (Collatio artis poetice probativa, ок. І40о) Николя де Гонесса, секретаря и исповедника маршала Бусико, переводчика Валерия Максима 4 . Идеи эти не утратили актуальности и в XVI в. Когда францисканец-неоплатоник Жан Тено (ок. I480-I542) создает на основе «Генеалогии богов» трактат о «поэтической науке» под названием «Род Сатурна» [22]5, предназначенный для будущего короля Франциска I, он почти дословно повторяет боккаччиевское определение поэзии как теологии или моральной философии: «Штудии поэтические <...> суть кладезь мудрости и основание Философии», ибо «поэтрия весьма изящно заключает в себе все науки, а именно богословие либо философию, как естественную, так и нравственную» ${ }^{6}$. «Басни» поэтов Тено, также вслед за Боккаччо, противопоставляет риторике с ее неоправданным многословием и установкой на delectatio и украшенную речь [22, p. І2г]. А ритор и поэт Пьер Фабри (или, во французском варианте, Лефевр; ок. I450 - ок. 1535) в прологе к своему «Великому и истинному искусству полной риторики» (I-е изд. I52I) для «оправдания» поэзии считает вполне достаточным просто сослаться на Боккаччо: «Тем, кто дурно отзывается о поэтах и называет их лжецами, ответ дает Боккаччо в начале своей Генеалогии богов. И теперь довольно мне сказать, что все Священное писание исполнено поэзии, как и Псалтирь: Упою стрелы Мои кровью, и меч Мой насытится плотью. И что еще важнее, Иисус Христос чаще всего говорил параболами, под каковыми прикровенными речами содержатся великие сущности. Так и в поэзии» 7 .

\footnotetext{
3 Так обстояло дело и в Италии. О судьбе «Генеалогии богов» во Франции см.: [9, 2г].

4 Публикацию трактата и его анализ см.: [8].

5 См. о нем, в частности: [5, р. 29-34].

6 «Lestude poeticque... est le puys de sapience et le fondement de Philosophie...»; «...touttes sciences sont contenues moult elegamment en poeterie, soit théologie ou philosophie tant naturelle que moralle» [22, p. 59, II $]$.

$7 \quad$ «Et a ceulx qui dient mal des poetes en les appellant menteurs, Bocasse au premier de sa Genealogie des Dieux leur en donne responce. Et pour le present me suffit de dire que toute saincte escripture est plaine de poesie, comme au psaultier: Inebriabo sagitas meas sanguine, et gladiis meus devorabit carnes. Et qui plus fort est, lesuchrist a le plus souuent parlé par parabolles, soubz
} 
Рецепция «Генеалогии...» на французской почве естественным образом сопровождалась переосмыслением установок, положенных Боккаччо в основу своего труда. Прежде всего это относится к общему замыслу итальянского гуманиста, который, как явствует из пролога-посвящения «Генеалогии...» королю Кипра Гуго IV Лузиньяну, стремился свести разбросанные по разным книгам сведения о «ложных» богах в единое целое. Сравнивая себя c «новым Эскулапом», восстановившим растерзанное тело Ипполита, он выстраивал генеалогическое древо, чтобы с его помощью найти разгадку «природным тайнам», скрытым под покровом родственных, любовных и прочих связей богов ${ }^{8}$. Составленная Боккаччо генеалогия - это попытка проникнуть в мысль древних и воссоздать скрытый в их вымыслах универсальный метафизический смысл: «Древо - не только форма классификации, упорядочение “сродства", которое придает смысл множественности богов в языческом политеизме: это сам по себе образ, аллегория первичной материи (hylê), которая, обретая форму (eidos), определяет, в соответствии с аристотелевой физикой, “источник” (archê), общий для всех творений природы. <...> Генеалогия богов, придуманная Боккаччо по образцу поэтов, эксплицитно представлена как поиск смысла: “восходя по спирали времен”, она охватывает мир “обзорным” взглядом, улавливая одновременно и момент его формирования, и момент изобретения богов, неотделимый от осознания первыми людьми своей связи с землей и небесами» [8]9. Кроме того - и это вторая важнейшая особенность «Генеалогии...», - каждый мифологический образ у флорентийского гуманиста полисемичен ${ }^{\text {го }}$. Воссоздание «древа-тела» античной мифологии позволяет не только свести вместе противоречивые сведения, рассыпанные в сочинениях древних, но и выявить множественность толкований божественных персонажей и их функций; при этом автор огова-

\footnotetext{
lesquelles parolles couuertes sont les grandes substances contenues. Ainsi est il des poesies» [ı, Livre I, p. I2]. В отличие от Тено, Фабри не противопоставляет поэзию риторике, а включает ее в последнюю (к этому вопросу мы еще вернемся).

8 «Ex quibus enucleationibus, preter artificium fingentium poetarum et futilium deorum consanguinitates et affinitates explicitas, naturalia quedam videbis tanto occultata misterio...» [4, Prohemium I].

9 Именно этой попыткой найти единый источник смысла объясняется появление в «Генеалогии...» фигуры прабожества - Демогоргона-демиурга.

IO «Sciendum est his fictionibus non esse tantum unicum intellectum, quin imo dici potest potius polisemum, hoc est moltiplicium sensum» [4, Liber I, III]. Та же мысль излагается и в прологе к первой книге.
} 
ривает свое право в случае необходимости «с величайшей охотой» предлагать по этому поводу собственные суждения [4, Prohemium I].

Однако французские последователи Боккаччо, в том числе и те, кто эксплицитно ссылался на его трактат (Жак Легран, Тено, Фабри), понимали свою задачу иначе. Прежде всего, «Генеалогия богов» с ее обширным мифологическим материалом встраивалась в традицию, заданную средневековыми мифографами - Фульгенцием, Альбрицием и др., - традицию, на которую флорентийский гуманист опирался, но в рамки которой его творение, безусловно, не укладывалось. Показательно, что первый французский перевод «Генеалогии...», выпущенный в I498 г. Антуаном Вераром $^{\text {II }}$ [5 (I5), № 56], включал в себя лишь тринадцать книг: «защита и прославление поэзии», предпринятая Боккаччо, в него не вошла. Чем бы ни было вызвано это сокращение - неисправной рукописью или, что скорее всего, сознательным намерением издателя, - оно привело к тому, что национальная версия «Генеалогии...» превратилась в пространный перечень античных богов и персонажей, аналогичный тем, что содержались во французских риторических и поэтических трактатах, начиная с «Красноречивейшей Софии-Мудрости» Леграна (Archiloge Sophie, ок. І4оо г.) и вплоть до «Олимпа Историй поэтических ${ }^{12}$, одного из переложений «Метаморфоз» Овидия (I539) ${ }^{\mathrm{r}}$.

Именно «Метаморфозы», а точнее, их анонимное морализованное переложение («Ovide moralisé», между I3I7 и I328 гг., посвящено Жанне Бургундской), к которому в середине XIV в. добавилась XV книга латинского «Нравственного свода» (Reductorium morale) Пьера Берсюира, более известная как «Ovidius moralizatus» ${ }^{14}$, по праву считаются основным источником и «генератором» подобных перечней во французской культуре; заложенная в этом переложении концепция мифологического вымысла и модель его аллегорической интерпретации оказалась во Франции

\footnotetext{
II Boccace de la geneologie des dieux. Explicit: Cy finist Jehan bocace de la genealogie des dieux Imprime nouuellement a Paris Lan mil CCCC. quatrevingtz et dixhuit le neufviesme le neufuiesme iour de feurier Pour Anthoine verard libraire demourant a Paris sur le pont nostre dame a lymage saint Iehan leuangeliste, ou au palais au premier pilier...

I2 Les XV livres de la Metamorphose D'ovide (Poëte treselegant) contenant L'olympe des Histoires poëtiques traduictz de Latin en Françoys, le tout figuré de nouvelles figures \& hystoires. Paris: Denis Janot, 1539 .

I3 О науке поэзии как каталоге см.: [7, p. 45-46].

I4 О ней и ее источниках см.: [гі].
} 
доминирующей, подчинив себе, в частности, метафизические разыскания Боккаччо. Для создателя «Морализованного Овидия» истинность любого текста, в том числе вымышленного и языческого, поверяется Священным Писанием, которое упомянуто уже в первом стихе:

Se l'escripture ne me ment,

Tout est pour nostre enseignement

Quanqu'il a es livres escript,

Soient bon ou mal li escript... [I8, Livre I, v. I-4]

(Коли не лжет Писание, все служит к нашему поучению, что написано в книгах, и хороших и плохих...)

«Истина..., покоящаяся под покровом басен» ${ }^{15}$, - это не множество возможных толкований, складывающихся в единство макрокосма, но иносказательно выраженное поучение, наставление в единственно истинной вере. Спустя почти полтора столетия автор (также анонимный) прозаической версии «Морализованного Овидия» (I466-I467, создана в Анже для Рене Анжуйского) выражает ту же идею более обстоятельно:

По слову монсеньора Св. апостола Павла, Писания написаны для учения и поучения нашего, дабы через терпение и утешение, в них содержащиеся, не оставляли мы надежды достигнуть славы, в каковую велит нам верить святая католическая вера <...> И оттого, что в сказанной книге «Метаморфоза» описано множество занятных вещей, каковые мудро изложены и истолкованы морально к доброму поучению и учению тех, кто их видел и увидит, занялся я тем, что изложил и переложил с латыни французскими рифмами басни сказанной книги, согласно пониманию моему ${ }^{16}$.

I5 «La veritez seroit aperte, Qui souz les fables gist couverte...» [I8, v. 45-46].

I6 «Selon que dit monseigneur Saint Pol apostre, les Escriptures sont escriptes à nostre doctrine et pour nostre enseignement, afin que par pacience et consolacion d'icelles nous avons esperance de parvenir à la gloire que saincte foy catholicque nous fait croire $<\ldots>$ Et pour ce que ou dit volume de Methamorphose sont escriptes de moult plaisans choses, lesquelles ont esté et sont saigement exposées et moralisées à la bonne eddificacion et doctrine de ceulx qui l'ont veü et verront, je me suis occupé à translater et exposer de latin en rime françoise les fables du dit volume selon que je les puis entendre» [19, p. 43]. Сопоставление стихотворной и прозаической версий «Морализованного Овидия» см. в статье Франсин Мора: [І7]. Существовала и вторая прозаическая версия, созданная в Брюгге ок. 1475 г. 
«Лживые басни» Овидия служат источником «великих истин и полезных моральных наставлений» ${ }^{17}$, только будучи истолкованы в «добром» свете Писания; иными словами, интерпретация оказывается первичной по отношению к мифологическому вымыслу, перемещая его в сферу «моральной философии» и превращая в exemplum, поучительный пример.

Из этого проистекают два важных следствия. Во-первых, целостная ткань античного мифа, которую стремился реконструировать Боккаччо, равно как и повествовательное единство «Метаморфоз», распадаются на отдельные элементы, каждый из которых может быть использован для дидактических нужд как сам по себе, так и в комбинации с другими. По справедливому замечанию В.Ю. Лукасик, «появление "Морализованного Овидия” в известном смысле утверждает за античным мифом в средневековой культуре Франции определенную роль: это набор сюжетных и этических элементов - нечто вроде рассыпанной головоломки. Ее нужно собрать заново, включив в состав более обширной мозаики, в которой каждый элемент попадет в правильное окружение...» [2, с. 9]. Отнюдь не случайно толкования Овидия у Берсюира разбиты на достаточно четко разграниченные рубрики, делающие любой отдельный фрагмент самодостаточным и позволяющие понять его вне связи с целым. Во-вторых, в рамках подобного экзегетического подхода поэтические «басни» древних оказываются функционально уравнены с библейскими сюжетами: и те и другие служат источником персонажей, мотивов и повествовательных схем, из которого «моральный философ» или проповедник может почерпнуть необходимый материал. Подобная функциональная «эквивалентность», намеченная еще у того же Берсюира, получила символическую фиксацию в одном из ключевых памятников французского позднего Средневековья - «Библии поэтов», выпущенной сначала в Брюгге Коларом Мансьоном (I484), а затем в Париже Антуаном Вераром (I493/4). Текст его представляет собой компиляцию, составленную Мансьоном из анонимного «Морализованного

I7 «Et combien que l'on les nomme fables et que aucuns les dient mensongieres, toutesvoies icelles bien entendues selon ce qu'elles seront cy apres exposées on y trouvera de grans verités et moralitez prouffitables assavoir, ja soit ce qu'elles soient enveloppées et couvertes subtillement soubz fictions» («И хотя именуют их баснями, и говорят некоторые, что они лживы, тем не менее в том добром понимании, как изложены они будут ниже, найдете вы в них великие истины и полезные моральные наставления, несмотря на то что тонко облечены они и скрыты под покровом вымыслов») [19, p. 43]. 
Овидия» и соответствующего сочинения Берсюира, которое Мансьон сам перевел на французский (и ошибочно приписал доминиканцу Томасу Валлийскому). В прологе к изданию Верара ${ }^{18}$ «оправдание» басен строится на двух главных аргументах: первым служит авторитет Ветхого и Нового Заветов, вторым - «польза», т. е. дидактическая функция, которую несет в себе вымысел, способный благодаря извлекаемому из него нравственному уроку направлять читателя или слушателя к добродетели и отвращать от порока:

Хотя некоторые невежды почитают вымыслы суетными баснями, каковым не следует давать никакой веры, однако отнюдь не разумно отбрасывать их вовсе. <...> По свидетельству евангелистов, Господь наш также, проповедуя в земной жизни, прибегал во многих местах к подобиям, параболам и вымышленным речам, отнюдь не затем, чтобы побудить народ свой верить в вымысел, но чтобы легче дать ему понять истину, под [оболочкой] этого вымысла заключенную. Верно и то, что у поэта либо оратора, великим красноречием наделенного, нельзя взять ни одной басни, каковая не была бы поучительна или не облекала какую-либо истину, отчего великие и мудрые клирики отнюдь их не отбрасывали, но извлекли из них аллегорически, морально, исторически или реально многие весьма полезные истины. <...> Потому извлекать истину из басни и поэтического вымысла полезно, и всяк человек должен делать это, дабы направить себя и ближнего к мудрости, добродетели и добрым нравам... ${ }^{\text {99. }}$

Сходным образом - через отсылку к библейским истинам и моральной пользе - разъясняет сущность и задачи «поэтрии», науки о вымысле,

I8 Автором пролога является сам Верар, использовавший в качестве образца пролог Мансьона. Оба текста и их сопоставительный анализ см.: [23, p. 269-280].

I9 «Combien que les fictions de aucuns vulgaires soient reputees choses vaines \& fabulatoires ausquelles ne fault adiouster aucune foy / Si nest il pas pourtant raisonnable que du tout on les rejette $<\ldots>$ Nostre seigneur aussi faisant en le terre ses predications selon le tesmoignage de ses euangelistes est veu user en plusieurs lieux de similitudes paraboliques \& parolles fainctes / Non pas pour vouloir induyre son peuple a croire la fiction mais pour plus facilement leur donner a entendre la verite soubz celle fiction enclose. Vray est aussi que iamais de poete ou orateur de haulte elloquence ne fut bonnement prinse fable qui ne fust exemplaire ou couuerture daucune verite parquoy les saiges \& grans clercs ne les ont point regettees / mais delles ont tire allegoriquement / morallement / historiallement ou reallement aucunes veritez moult prouffitables. $<\ldots>$ Par quoy tirer verite de fable et poeticque fiction est prouffitable: Et ce doit faire tout homme pour induyre lui et autrui a sapience vertuz et bonnes meurs...» [3, f. Aii r-Aii v; I6, № 3I]. 
августинец Жак Легран, посвятивший ей специальную главу во II книге своей «Красноречивейшей Софии-Мудрости» $[\mathrm{I} 4]^{20}-$ «O поэтрии и как должно ее применять» (De poeterie et comment on doit user de icelle).

Поэтрия имеет целью своей и задачей создавать вымышленные истории и иные вещи, в зависимости от того, о чем мы желаем говорить. И на то указывает само ее имя, ибо поэтрия есть не что иное как наука о сложении вымыслов <...> Поэтрия научает создавать добрые и разумные вымыслы, и потому святой Августин в первой книге своей «Исповеди», рассуждая о поэтах, говорит и признает, что нашел у них, сиречь у поэтов, много полезных речей. А иногда и Священное писание прибегает к вымыслам...2 .

«Поэтрия» - это квинтэссенция ученого, книжного знания (она учит «кстати применить к тому, о чем говоришь, некие истории либо некие вымыслы, но никто не может этого сделать, не прочитав многих историй либо многих вымыслов» ${ }^{22}$ ), которая у Леграна принимает форму каталога примеров, или «ссылок» (allegacions). Причем, хотя структура многостраничного списка повторяет порядок книг «Метаморфоз», глосса-морализация оказывается первичной: она выносится в название рубрики - в отличие от Фульгенция или «Морализованных Овидиев», где она следовала за овидиевским текстом как его экспликация. Иными словами, Легран редуцирует «Метаморфозы» до набора категорий - пороков и добродетелей, социальных и человеческих свойств (Правосудие, Изобилие, Гордыня, Лесть, Тирания, Уродство, Зависть, Дурной Совет и т. п.). После мифологического каталога Легран помещает аналогичный, но более краткий список «басен», почерпнутых из Библии.

\footnotetext{
20 Книга представляет собой французскую расширенную версию латинского трактата Леграна «Sophilogium» (до г4ог г.).

2I «La fin et l'entenion de poeterie si est de faindre hystoires ou autres choses selon le propos du quel on veult parler. Et de fait son nom se demonstre, car poetrie n'est autre chose a dire nemais science qui aprent a faindre. $<\ldots>$ Poetrie en soy aprent a faire fictions bonnes et raisonnables et pour tant saint Augustin ou premier livre de ses confessions en parlant des poetes dit et confesse que pluseurs paroles prouffitables il a trouvé en eulx, c'est assavoir es poetes. Et de fait la Sainte Scripture aucunefois use de fictions...» [14, p. I49, I53-I54].

22 «A son propos aucunes hystoires ou aucunes fictions alleguier ou appliquier, mais ce faire nul ne puet s'il n’a veu pluseurs hystoires ou pluseurs fictions» [I4, p. 156].
} 
Главный принцип Боккаччо - полисемия античного мифа, чье множественное аллегорическое толкование призвано реконструировать его имманентную цельность, оказывается разрушен окончательно. У Леграна «речь идет уже не о том, чтобы вычленить различные семы басни, но о том, чтобы наилучшим образом использовать пустую оболочку, остающуюся от мифа, из которого все его различные значения уже извлечены» [5, p. 25].

Однако тем самым науке о вымыслах, морализованных, разъятых на отдельные loci communes и классифицированных по категориям «моральной философии», отводится в системе знания иное, нежели у Боккаччо, место. Поскольку поэтрия «имеет целью своей и задачей создавать вымышленные истории и иные вещи, в зависимости от того, о чем мы желаем говорить», она является частью риторики:

И наука эта премного нужна тем, кто хочет красиво говорить; а потому поэтрия, по мнению моему, подчинена риторике. Правда, некоторые говорят иное, как аль-Фараби в своей «Книге о разделении наук», каковой говорит, что поэтрия есть последняя часть логики. И еще он говорит, что поэтрия есть наука, научающая слагать стихи и подчинять слова свои и речи некому размеру; но, полагаю я, мнение это неразумно, ибо поэтрия отнюдь не учит доказывать, что делает логика. И поэтрия отнюдь не наставляет в науке слагать стихи, ибо наука эта частью относится к грамматике, а частью - к риторике...23.

Как следствие, «басни», превращенные в exempla, принадлежат у Леграна к сфере не столько inventio, сколько elocutio, становятся разновидностью риторических фигур. Приведенный в «Красноречивейшей Софии» перечень таких фигур, т. е. мифологических и библейских мотивов с заранее заданной семантикой, призван сообщить речи говорящего/пишущего поэтический характер; иными словами, Легран создает первый в национальной традиции словарь поэтического языка.

23 «t est ceste science moult necessaire a ceulx qui veulent beau parler; et pour tant poetrie a mon advis est subalterne de rethorique. Bien est vray que aucuns dient l'opposite, comme Alpharabe en son livre de la division des sciences, le quel dit que poetrie est la derreniere partie de logique. Et dit oultre plus que poetrie est science qui apprent a versifier et a ordonner ses moz et ses paroles par certaine mesure; mais a mon avis ceste opinion n'est mie raisonnable: car poetrie n'apprent point a arguer, la quelle chose fait logique. Poetrie aussi ne monstre point la science de versifier: car telle science appartient en partie a gramaire et en partie a rethorique...» [I4, p. I49]. 
Более того, поэтический язык выступает у него не только предметом описания. Трактат открывается стихотворным прологом, где МудростьСофия представлена в виде Дамы, к которой обращены речи влюбленного - Фило [14, p. 26]. Любовь к Мудрости уподоблена любви к даме: языком истинной философии предстает поэзия. Следует подчеркнуть, что пролог и толкование присутствуют лишь во французском тексте, но не в латинском: поэтический вымысел служит риторическим эквивалентом философии на пространстве именно народного языка. Последний благодаря «басне», выстроенной на этимологии слова «философ», обретает способность передавать свет божественного знания, который несет в себе фигура Софии.

«Поэтическая» форма возлюбленной Фило прямо отсылает к ее античному происхождению. По словам самой Софии, она родилась в Афинах, причем матерью ее была Минерва, а отцом - Улисс. Эта «генеалогия» заключает в себе двоякий смысл. Во-первых, Легран отождествляет мудрость со сферой studia humanitatis: указывая на Афины как на родину Мудрости, он прямо соотносит предмет своего произведения с наследием античных auctores. Во-вторых, описывая дальнейшее «путешествие» Софии из Афин в Рим, а из Рима - в Париж, Легран воспроизводит идею translatio studii, посредством которой ранний французский гуманизм заявлял о себе как о прямом наследнике античного знания и утверждал свое превосходство перед гуманизмом итальянским.

Эта идея «переноса» античной философской мудрости на национальную почву имела ряд важных следствий. Как уже было сказано, благодаря ей национальная поэзия включалась в сферу «ученого», книжного знания, т. е. в сферу риторики с ее философским обоснованием. Легран в латинской версии трактата распространял действие законов поэтрии как на стихи, так и на прозу: «Предмет поэтрии - не сложение стихов, но умение слагать вымыслы, либо в прозе, либо размером» ${ }^{24}$. Однако объединение стихотворства и поэтрии вплоть до конца XV в. было характерно не столько для национальной, сколько именно для гуманистической традиции. Например, Робер Гаген в предисловии к своему «Искусству стихосложения» (ок. I473) повторяет восходящую к Боккаччо (и Леграну) топику «оправдания» поэтического вымысла - но применительно к стихотворству:

24 «Poetria non habet pro objecto metrificare, sed potius fingere, sive sit in prosa, sive in metro» [цит. по: І3, p. Х]. Во французском тексте эта оговорка отсутствует. 
Люди, желающие казаться учеными, полагают, будто стихотворство относится к ничтожной и праздной дисциплине, как если бы оно было противно христианской религии и добропорядочной жизни. В самом деле, Муз и сладостные поэмы, из коих, по их убеждению, проистекает мастерство стихотворства, они проклинают не хуже чумы и считают, что стихи суть попросту изобретения развратных авторов, каковые почитали всю эту толпу давно изгнанных ложных богов [цит. по: 6, p. І46].

В национальной же словесности стихотворство обрело статус риторического искусства в трактатах по «второй риторике» (seconde rhétorique, т. е. версификации на народном языке, в отличие от прозы, прежде всего латинской), созданных на протяжении XV столетия. Однако подавляющее большинство этих трактатов посвящены фиксированным формам, в основном унаследованным от куртуазной лирики, и какое бы то ни было упоминание роetrie в них отсутствует. Единственным исключением служат анонимные «Правила второй риторики», написанные, по мнению Э. Ланглуа, между I4II и I432 гг. неким уроженцем северной или северо-восточной Франции, которому были лучше известны произведения участников разного рода поэтических состязаний («пюи»), процветавших в этом регионе, нежели творчество придворных поэтов [г3, p. XXVII]. Лишь этот автор включает в свой трактат обширный перечень «фигур», где библейские персонажи соседствуют с персонажами античной мифологии, а также «имен поэтов, богов и богинь, философов, патриархов и волшебников, согласно поэтрии некоторых благородных философов и поэтов» 25 .

В этом списке обращают на себя внимание две особенности. В отличие от каталога Леграна, где древние боги и герои перечислены в порядке книг Овидия и отделены от библейского перечня, он не подчинен логике классификации: персонажи Библии и античного мифа упоминаются вперемешку. Кроме того, среди них присутствуют имена Евклида, Сенеки и Овидия, «доблестного поэта» [І3, р. 67], как бы олицетворяющие поэзию в трех ее ипостасях, музыкальной, моральной и ученой: Евклид назван изобретателем ритма в музыке, Сенека - родоначальником нравственной философии, а Овидий воплощает книжное знание. Во-вторых, - и это глав-

25 «Item, cy après s'ensivent aucuns noms de poetes, de dieux, de deesses, de philosophes, de patriarches et de magisciens, selonc la poetrie d'aucuns generaulx philozophes et poetes» [I3, p. 65]. 
ное - ни одна из фигур, за редчайшими исключениями, не снабжена ни морализацией, ни каким-либо иным толкованием; автор лишь поясняет, кем является данный персонаж, и пересказывает, с разной степенью подробности, связанные с ним сюжеты, зачастую довольно причудливого свойства ${ }^{26}$. Это уже поэтический словарь в чистом виде, аналогичный многостраничным спискам поэтической лексики у Боде Геренка: отнюдь не случайно между Эолом и подвигами Марса вклинивается толкование слов «deformité» (уродство) и «соеqualité» (подобие) [г3, р. 70]. Сходным образом строится и анонимное «Искусство и наука риторики на народном языке» (ок. I524-I525) [13, р. 265-426], представляющее собой переработку «Искусства риторики» Жана Молине (между I482 и I492 гг.): оно содержит обширный словарь лексики и рифм, в который включено несколько античных имен, однако уже не богов, а великих мастеров, прославившихся в разных сферах искусства Праксителя, Апеллеса, Вергилия, Плиния (а также Жана Жерсона).

Фактически проникновение идей poetrie в национальную словесность вплоть до конца XV столетия не подвергалось эксплицитному теоретическому осмыслению. Так, в творчестве «великих риториков» мифологический материал редко сочетается со стихотворными формами (предметом «второй риторики»): как правило, он используется в новых жанрах, разработанных этой школой, особенно в прозометрических «храмах» ${ }^{27}$, наделенных выраженной дидактической функцией. Кроме того, само представление о поэзии как о самостоятельной области риторики вплоть до последней четверти XV в. не было актуальным при французском дворе, где освоение этой идеи было связано с деятельностью придворного

\footnotetext{
26 В трактате прослеживается, однако, очевидное стремление подчеркнуть в сюжетах поэтическую составляющую и связать их с национальной стихотворной традицией: так, муза Каллиопа, превращенная в «Правилах...» в идеал верного любовника, сочиняет «смертное лэ» [І3, p. 39]. В истории Пирама и Фисбы главным оказывается то, что лев, растерзавший Фисбу, прибежал на звук лэ, которое она пела, ожидая Пирама; Пирам же, убив льва, также запевает смертное лэ [ı3, p. 48]. Среди античных богов возникают аллегории-персонификации, напоминающие персонажей «Романа о Розе»: например, в изложении мифа о Парисе и золотом яблоке упомянута «богиня лени, именуемая Раздором» (deesse de paresse, nommée Destourbe) [13, p. 47].

27 Ср., например, характерный перечень богов в «Храме Марса» Молине: «Je saluay iupiter saturnus / Pluto: iuno: palas mercure / Proserpina: cibulus: vulcanus / Phebe: phebus: pheton: pan siluanus / Et neptunus qui la mer en cure...» («Я поклонился Юпитеру, Сатурну, Плутону, Юноне, Палладе, Меркурию, Прозерпине, Кибеле, Вулкану, Фебе, Фебу, Фаэтону, Пану, жителю лесов, и Нептуну, повелителю моря») [г6].
} 
чтеца Карла VIII, гуманиста Гийома Тардифа, а также либрария Антуана Верара, изготовившего для короля подносное издание «Искусства риторики» Молине $^{28}$. Наука о вымысле в боккаччиевском смысле была окончательно зафиксирована во французской словесности лишь к началу XVI в., у Жана Тено. Однако уже «Великое и истинное искусство полной риторики» Пьера Фабри со всей очевидностью демонстрирует, что учение о fabula оказалось полностью подчинено принципу «украшенной речи», пополнив собой набор риторических фигур, необходимых оратору:

Оратор должен быть поэтом, ибо риторика предполагает знание всех прочих наук и в особенности поэзии, каковая в себе содержит все цветы изящного сочинительства ${ }^{29}$.

А автор «Олимпа историй поэтических» ${ }^{\circ}$, включая в заглавие прямое отождествление овидиевских «басен» с риторическими фигурами (le tout figuré de nouvelles figures $\mathcal{E}$ hystoires), во втором прологе к своему сочинению заявляет, что традиция библейской экзегезы применительно к Овидию завершена, и необходимости в ней больше нет:

Поэзия, мать хитроумной и радостной инвенции под покровом изящной Басни, столь верно изъяснила учение моральное и человеческое, что ежели способность к пониманию у читателя не совсем уничтожена невежеством, то он извлечет из нее честные поучения и правила доброй жизни: ибо сие есть не что иное, как скрытая философия, к каковой Святой Августин во второй книге своего Учения христианского запрещает давать аллегории, ибо она достаточно аллегорична сама по себе. Посему в этом великом Олимпе все они изъяты, а сохранено естество Автора....

28 Описание и историю этого издания см.: [23, p. 94-96].

29 «'orateur doit estre poete, car rethorique presuppose toultes les aultres sciences estre sceuez et especiallement poesie qui contient toutes les fleurs de elegante composition» [IO, p. II-I2] 30 Les XV livres de la Metamorphose D'ovide (Poëte treselegant) contenant L'olympe des Histoires poëtiques traduictz de Latin en Françoys, le tout figuré de nouvelles figures \& hystoires. Paris: Denis Janot, I539.

3I «Poesie mere de subtille \& joyeuse invention soubz une couverte de Fable elegante a si vrayement exprimé la doctrine moralle \& humaine, que si l'entendement du liseur n'est du tout effacé par ignorance, il en tirera honnestes enseignements \& maniere de bien vivre : car ce n'est que pure philosophie latente, à laquelle Sainct Augustin au ii. De sa doctrine Chrestienne prohibe faire 
Отсылка (фиктивная) к авторитету Августина призвана утвердить новый статус поэтического вымысла: сохраняя свою аллегорико-морализаторскую природу, он больше не нуждается в эксплицитном толковании. «Басня» самодостаточна, и образованный читатель, наделенный «пониманием», способен интерпретировать ее без посредничества комментатора-наставника.

Таким образом, рассмотрев некоторые аспекты понятия аллегории во французской словесности позднего Средневековья и его взаимосвязь с наукой о поэзии (поэтрией), мы можем констатировать, что концепция «басни» как аллегорического вымысла сыграла значительную роль в теоретическом осознании национальной литературной традиции. Благодаря рецепции идей, почерпнутых из «Генеалогии богов» Боккаччо, стала возможной выработка норм французской риторики. Смысл превращения материала античного мифа в набор риторических фигур, придающих тексту «поэтический» характер, не сводится к одной лишь упрощающей редукции: оно позволило поставить творения античных авторов на службу красноречию на народном языке и тем самым повысить его культурный статус.

\section{Список литературы}

I Боккаччо Дж. Генеалогия языческих богов / пер. В. Бибихина // Эстетика Ренессанса. М.: Искусство, І98І. Т. II. С. II-63.

2 Лукасик В.Ю. Миф до Ренессанса: Античная мифология во французской поэзии позднего Средневековья. М.: Книжный дом «ЛИБРОКОМ», 20II. 223 с.

3 La bible des poetes. methamorphoze. nouuellement imprime a paris. Explicit: Cy finist la bible des poetes de methamorphoze. Imprime a paris ce premier iour de mars mil quatre cens quatre vings et treze par anthoine verard libraire demourant a paris sur le pont nostredame a lymaige sainct iehan leuangeliste ou au palais au premier pillier ou on chante la messe des presidens (BNF Rés. Vélins 559) Available at: http://gallica. bnf.fr/ark:/I2I48/bpt6k709675.r=La\%2oBible\%2odes\%2opo\%C3\%ABtes\%2C\%2O M\%C3\%A9tamorphose\%2od'Ovide (Accessed I5 March 20I7).

4 Boccaccio G. Genealogia degli Dei / A cura di Lucio Tarzariol. Available at: http:// spazioinwind.libero.it/reminiscenti/Genealogia_degli_Dei_di_Giovanni_Boccaccio. pdf (Accessed I5 March 20I7).

allegories, comme assez d'elle mesmes allegorisant. Parquoy en ce grand Olympe sont obmises en gardant le naturel de L'auteur...» [5, p. 47]. 
Campagne H. Mythologie et rhétorique aux XVe et XVIe siècles en France. Paris: H. Champion, I996. 293 p.

Charrier S. Recherches sur l'œuvre latine en prose de Robert Gaguin (I433-I5OI).

Paris: H. Champion, I996. 576 p. (Bibliothèque littéraire de la Renaissance: série 3; 35). héritage en France au XVIe siècle / sous la dir. de P. Galand-Hallyn et F. Hallyn. Genève: Droz, 200I. P. 29-52.

8 Di Stefano G. Multa mentiere poetae: le débat sur la poésie de Boccace à Nicolas de Gonesse. Montréal: CERES, I989. 79 p.

9 Di Stefano G. Il Trecento // Il Boccaccio nella cultura francese. Firenze: Olschki, I97I. P. I-47.

Io Fabri P. Le Grand et vrai art de pleine rhétorique. Livres I-III / publ. avec introd., notes et glossaire par A. Héron. Genève: Slatkine Reprints, I969. 310, I40, XXXV, I36 p.

II Ghisalberti F. Ovidius Moralizatus di Pierre Bersuire. Roma: Cuggiani, I933. I36 p.

I2 Graziani F. Mythologia, Genealogia, Archaiologia: Fonction paléontologique de la mythographie // Kernos. Revue internationale et pluridisciplinaire de religion grecque antique. 2006. № 19. Available at: http://kernos.revues.org/450 DOI : I0.4000/ kernos.450 (Accessed I5 March 2017).

I3 Langlois E. Recueil d'arts de seconde rhétorique. Paris: Imprimerie nationale, I9O2. LXXXVIII-498 p.

I4 Legrand J. Archiloge Sophie. Livre de bonnes meurs / ed. critique avec introd., notes et index par E. Beltran. Paris: H. Champion, I986. 430 p. (Bibliothèque du XVe siècle, XLIX).

I5 Macfarlane J. Antoine Vérard. Genève: Slatkine Reprints, I97I. I43 p.

I6 Molinet J. Le temple de mars dieu de bataille. S.l. s.d. Available at: http://gallica.bnf.fr/ ark:/I2I48/bpt6k720I7m.r=Molinet\%20Temple\%2ode\%20Mars (Accessed I5 March 2017).

I7 Mora F. Deux réceptions des Métamorphoses au XIVe et XVe siècle. Quelques remarques sur le traitement de la fable et de son exégèse dans l'Ovide moralisé en vers et sa première mise en prose // Cahiers de Recherches Mediévales et Humanistes. 2002. № 9: Lectures et usages d'Ovide Available at: https://crm.revues.org/64\#ftn4 (Accessed I5 March 20I7).

I8 Ovide moralisé. Poème du commencement du quatorzième siècle publié d'après tous les manuscrits connus / par C. De Boer. Amsterdam: Müller, I9I5. Vol. I. 782 p.

I9 Ovide moralisé en prose: texte du XV siècle / ed. critique par C. De Boer. Amsterdam: North Holland Pub. Co, I954. 408 p.

20 Pionchon $P$. La Généalogie des dieux païens entre le Décaméron et les nouvelles des humanistes du premier XVe siècle // Cahiers d'études italiennes. 20IO. № Io. Nouvelle et roman. P. $55^{-78}$. 
2I Sozzi L. Boccaccio in Francia nel Cinquecento // Il Boccaccio nella cultura francese. Firenze: Olschki, I97I. P. 2II-349.

22 Thénaud J. La Lignée de Saturne. Ouvrage anonyme (B.N. Ms. Fr. I358). Suivi de La Lignée de Saturne ou le Traité de science poétique (B.N. Ms. Fr. 208I) / textes éd. et prés. avec notes et commentaires par G. Mallary Masters avec la collab. d'Eliane Jasenas. Genève: Droz, I973. I74 p. (Travaux d'humanisme et Renaissance, I30). Winn M. B. Anthoine Vérard, Parisian Publisher. I485-15I2. Prologues, Poems and Presentations. Genève: Librairie Droz, 1997. 555 p. (Travaux d'humanisme et Renaissance, 3I3).

\section{References}

I Bokkachcho Dzh. Genealogiia iazycheskikh bogov [Genealogy of the Pagan Gods], trans. V. Bibikhin. Estetika Renessansa [Renaissance aesthetics]. Moscow, Iskusstvo Publ., I98I, vol. II, pp. II-63 (In Russ.)

2 Lukasik V.Iu. Mif do Renessansa: Antichnaia mifologiia vo frantsuzskoi poezii pozdnego Srednevekov'ia [Myths before the Renaissance: Classical mythology in the French poetry of the Late Middle Ages]. Moscow, Knizhnyi dom “LIBROKOM” Publ., 2OII. 223 p. (In Russ.)

3 La bible des poetes. methamorphoze. nouuellement imprime a paris. Explicit: Cy finist la bible des poetes de methamorphoze. Imprime a paris ce premier iour de mars mil quatre cens quatre vings et treze par anthoine verard libraire demourant a paris sur le pont nostredame a lymaige sainct iehan leuangeliste ou au palais au premier pillier ou on chante la messe des presidens (BNF Rés. Vélins 559). Available at: http://gallica. bnf.fr/ark:/r2I48/bpt6k709675.r=La\%2oBible\%2odes\%2opo\%C3\%ABtes\%2C\%2O M\%C3\%Agtamorphose\%2od'Ovide (Accessed I5 March 20I7). (In French) Boccaccio G. Genealogia degli Dei, a cura di Lucio Tarzariol. Available at: http:// spazioinwind.libero.it/reminiscenti/Genealogia_degli_Dei_di_Giovanni_Boccaccio.pdf (Accessed I5 March 20I7). (In Italian)

5 Campagne H. Mythologie et rhétorique aux XVe et XVIe siècles en France. Paris, H. Champion, 1996. 293 p. (In French)

6 Charrier S. Recherches sur l'œuvre latine en prose de Robert Gaguin (I433-I5OI). Paris, H. Champion, I996. 576 p. (Bibliothèque littéraire de la Renaissance : série 3; 35) (In French)

$7 \quad$ Cornilliat F., Mühlethaler J.-C., Dull O.A. La poésie parmi les arts au XVe siècle. Poétiques de la Renaissance. Le modèle italien, le monde franco-bourguignon et leur héritage en France au XVIe siècle, sous la dir. de P. Galand-Hallyn et F. Hallyn. Genève, Droz, 200I, pp. 29-52. (In French)

8 Di Stefano G. Multa mentiere poetae: le débat sur la poésie de Boccace à Nicolas de Gonesse. Montréal, CERES, I989. 79 p. (In French) 
9 Di Stefano G. Il Trecento. Il Boccaccio nella cultura francese. Firenze, Olschki, I97I, pp. I-47. (In Italian)

Io Fabri P. Le Grand et vrai art de pleine rhétorique. Livres I-III, publ. avec introd., notes et glossaire par A. Héron. Genève, Slatkine Reprints. I969. 310, I40, XXXV, I36 p. (In French)

II Ghisalberti F. Ovidius Moralizatus di Pierre Bersuire. Roma, Cuggiani, I933. I36 p. (In Italian)

I2 Graziani F. Mythologia, Genealogia, Archaiologia: Fonction paléontologique de la mythographie. Kernos. Revue internationale et pluridisciplinaire de religion grecque antique, 2006, no I9. Available at: http://kernos.revues.org/450 DOI: I0.4000/ kernos.450 (Accessed I5 March 20I7). (In French)

I3 Langlois E. Recueil d'arts de seconde rhétorique. Paris, Imprimerie nationale, I902. LXXXVIII-498 p. (In French)

I4 Legrand J. Archiloge Sophie. Livre de bonnes meurs, éd. critique avec introd., notes et index par E. Beltran. Paris, H. Champion, I986. 430 p. (Bibliothèque du XVe siècle, XLIX) (In French)

I5 Macfarlane J. Antoine Vérard. Genève, Slatkine Reprints, I97I. I43 p. (In French)

I6 Molinet J. Le temple de mars dieu de bataille. S.l. s.d. Available at: http://gallica.bnf.fr/ ark:/I2I48/bpt6k72OI7m.r=Molinet\%20Temple\%2ode\%20Mars (Accessed I5 March 20I7). (In French)

I7 Mora F. Deux réceptions des Métamorphoses au XIVe et XVe siècle. Quelques remarques sur le traitement de la fable et de son exégèse dans l'Ovide moralisé en vers et sa première mise en prose. Cahiers de Recherches Mediévales et Humanistes, 2002, no 9: Lectures et usages d'Ovide. Available at: https://crm.revues.org/64\#ftn4 (Accessed I5 March 20I7). (In French)

I8 Ovide moralisé. Poème du commencement du quatorzième siècle publié d'après tous les manuscrits connus, par C. De Boer. Amsterdam, Müller, I9I5. Vol. I. 782 p. (In French)

I9 Ovide moralisé en prose: texte du XV siècle, éd. critique par C. De Boer. Amsterdam, North Holland Pub. Co, I954. 408 p. (In French)

20 Pionchon P. La Généalogie des dieux païens entre le Décaméron et les nouvelles des humanistes du premier XVe siècle. Cahiers d'études italiennes, 20Iо, no Io, Nouvelle et roman, pp. 55-78. (In French)

2I Sozzi L. Boccaccio in Francia nel Cinquecento. Il Boccaccio nella cultura francese. Firenze, Olschki, I97I, pp. 2II-349. (In Italian)

22 Thénaud J. La Lignée de Saturne. Ouvrage anonyme (B.N. Ms. Fr. 1358). Suivi de La Lignée de Saturne ou le Traité de science poétique (B.N. Ms. Fr. 208I), textes éd. et prés. avec notes et commentaires par G. Mallary Masters avec la collab. d'Eliane Jasenas. Genève, Droz, I973. I74 p. (Travaux d'humanisme et Renaissance, I30). (In French)

23 Winn M. B. Anthoine Vérard, Parisian Publisher. I485-I5I2. Prologues, Poems and Presentations. Genève, Librairie Droz, I997. 555 p. (Travaux d'humanisme et Renaissance, 3I3). (In English) 